\title{
Keefektifan Model Make A Match Berbantu Media Kartakalung Terhadap Hasil Belajar Matematika Siswa
}

\author{
Aulia Nofa Gayatri ${ }^{*}$, Henry Januar Saputra ${ }^{2}$, Mei Fita Asri Untari ${ }^{3}$ \\ 1,2,3 Pendidikan Guru Sekolah Dasar, FIP, Universitas PGRI Semarang
}

A R T I C L E I N F O

Article history:

Received 22 August 2018

Received in revised form

10 September 2018

Accepted 16 October 2018

Available online 29

November 2018

\section{Kata Kunci:}

keefektifan, hasil,belajar,

matematika.

Keywords:

effectiveness, results,

learning, mathematics.

\begin{abstract}
A B S T R A K
Permasalahan yang dibahas dalam penelitian ini adalah hasil belajar Matematika siswa yang masih sangat rendah. Permasalahan dalam penelitian ini adalah apakah Model Pembelajaran Make a Match Berbantu Media Kartakalung Terhadap Hasil Belajar Matematika Siswa Kelas V SD Negeri Karangroto 04 Semarang? Tujuan dalam penelitian ini adalah untuk mengetahui keefektifan model pembelajaran Make a Match berbantu media Kartakalung terhadap hasil belajar Matematika kelas V SDN Karangroto 04 Semarang. Jenis penelitian ini adalah penelitian kuantitatif dengan desain penelitian Pre-Experimental Design. Bentuk pre-experimental design yang digunakan dalam penelitian ini adalah One-Group Pretest-Posttest Design. Sampel yang diambil adalah 25 siswa kelas V. Data dalam penelitian ini diperoleh melalui tes, dokumentasi, dan observasi. Hasil nilai rata-rata pretest dan posttest mengalami peningkatan. Pada nilai pretest yang telah dilaksanakan diperoleh nilai rata-rata sebesar 65 dan tes akhir posttest nilai rata-rata sebesar 81. Hasil pengujian hipotesis pada hasil belajar Matematika siswa menunjukkan bahwa t_hitung 5,665 dan ttabel 2,060 dengan taraf
\end{abstract} signifikan 5\% =2,060. Karena t_hitung>t_tabel, yaitu 5,665 > 2,060 maka Ha diterima.

Berdasarkan hasil penelitian ini saran yang dapat disampaikan adalah supaya model pembelajaran Make a Match berbantuan media Kartakalung dapat digunakan sebagai salah satu alternatif guru dalam mengajar.

\section{A B S T R A C T}

The problems discussed in this study are student mathematics learning outcomes which are still very low. The problem in this study is whether the Make a Match Learning Model Helped by Media Kartakalung Against Mathematics Learning Outcomes of Grade V Students of Karangroto 04 Elementary School Semarang? The purpose of this study was to determine the effectiveness of the Make a Match learning model supported by Kartakalung's media on the mathematics learning outcomes of fifth grade Karangroto 04 Elementary School Semarang. This type of research is quantitative research with Pre-Experimental Design research design. The form of pre-experimental design used in this study was One-Group Pretest-Posttest Design. The samples taken were 25 class $V$ students. The data in this study were obtained through tests, documentation, and observations. The results of the average pretest and posttest have increased. At the value of the pretest that has been carried out obtained an average value of 65 and the final test posttest average value of 81 . The results of hypothesis testing on mathematics learning outcomes of students showed that $t$ count 5.665 and ttable 2.060 with a significant level of $5 \%=2.060$. Because $t$ count $>t$ table, which is $5.665>2.060$, $\mathrm{Ha}$ is accepted. Based on the results of this study the suggestions that can be conveyed are that the Make a Match learning model supported by Kartakalung's media can be used as an alternative teacher in teaching. 


\section{Pendahuluan}

Pendidikan adalah kegiatan atau proses memanusiakan manusia, yang terjadi dan dengan kebudayaan, yang di sebut proses hominisasi dan humanisasi" Drijarkara ( dalam Soegeng 2013: 54-55). Pendidikan adalah usaha sadar dan terencana untuk mewujudkan suasana belajar dan proses pembelajaran agar pesera didik secara aktif mengembangkan potensi dirinya untuk memiliki kekuatan spiritual, keagamaan, pengendalian diri kepribadian, kecerdasan akhlak mulia, serta ketrampilan yang diperlukan dirinya, masyarakat, bangsa dan negara (UU RI Nomor 20 Tahun 2003 tentang Sisdiknas).

Dari pasal tersebut dapat di simpulkan bahwa fungsi pendidikan salah satu sarana bagi peserta didik atau proses sosial dimana seseorang akan di hadapkan pada lingkungan terpilih yang akan membuat perubahan tingkah laku pada setiap individu tersebut. Untuk mendapatkan pendidikan yang layak siswa harus mengalami pendidikan di sekolah, karena di sekolah siswa akan di ajarkan berbagai mata pelajaran seperti matematika,IPA,IPS, dan juga Bahasa Indonesia.

Untuk menciptakan proses pembelajaran yang berkualitas ada berbagai macam cara yang dapat dilakukan guru, salah satunya dengan menggunakan model pembelajaran yang menarik untuk menambah minat siswa dalam mengikuti proses pembelajaran agar tidak bosan dan jenuh. Apalagi mengingat pembelajaran matematika yang selalu ditakuti siswa dan dianggap mata pelajaran paling sulit. Menurut Wiguna (2015) pembelajaran Matematika di SD merupakan pondasi yang kokoh untuk dapat memasuki jenjang pendidikan yang lebih tinggi dan juga untuk menghadapi tantangan perkembangan ilmu pengetahuan dan teknologi (IPTEK). Menjadikan peran guru sangat berpengaruh dalam proses pembelajaran bagaimana membuat kegiatan pembelajaran matematika menyenangkan dan tidak menjadi momok yang menyeramkan bagi siswa.

Berdasarkan hasil wawancara mengenai kegiatan pembelajaran dengan guru kelas V SD Negeri Karangroto 04 Semarang yaitu guru menjelaskan bahwa dalam proses pembelajaran guru sudah memberikan pengajaran yang baik kepada siswa namun masih menemukan permasalahan dalam pembelajaran matematika dimana siswa merasa kesulitan dalam mengerjakan soal. Hal tersebut dikarenakan pada saat kegiatan belajar mengajar berlangsung sebagian siswa masih kurang antusias memperhatikan penjelasan guru. Siswa masih aktif berbicara namun bukan dalam konteks kegiatan pembelajaran yang sedang berlangsung. Selain itu, faktor lain yang mempengaruhi rendahnya hasil belajar siswa, yaitu minimnya rasa percaya diri dan keberanian siswa dalam mengajukan pertanyaan mengenai materi yang disampaikan oleh guru atau mengemukakan pendapat saat kegiatan belajar mengajar berlangsung.

Solusi untuk mengatasi masalah tersebut yaitu seiring dengan perkembangan dan kemajuan dalam dunia pendidikan, pola-pola pengajaran modern mulai dikembangkan dalam kegiatan pembelajaran seperti halnya model-model pembelajaran yang lebih inovatif. Peneliti mencoba melakukan penelitian dengan menggunakan model pembelajaran untuk melatih pola piker siswa untuk meningkatkan hasil belajar siswa.

Model Pembelajaran yang di gunakan yaitu Make A Match (Mencari Pasangan Kartu). Dengan harapan dilaksanakannya penelitian ini dapat meningkatkan hasil belajar Matematika siswa kelas V SDN Karangroto 04 Semarang. Alasan memilih Model Pembelajaran Make A Match yaitu model pembelajaran yang menyenangkan dimana siswa dituntut berperan aktif selama proses pembelajaran sehingga di harapkan dapat meningkatkan hasil belajar siswa.

Salah satu faktor yang juga berpengaruh terhadap keberhasilan pembelajaran adalah media pembelajaran yang di gunakan oleh guru dalam proses pembelajarannya. Karena media pembelajaran merupakan segala sesuatu yang dapat di gunakan untuk menyalurkan pesan dan merangsang terjadinya proses belajar pada siswa (Aqib, 2013:50). Kemampuan seorang guru dalam menyusun dan menerapkan media pembelajaran yang merupakan kunci dari keberhasilan proses pembelajaran yang menyenangkan.

Media kartu tebak kata berkalung adalah media pembelajaran berbentuk kartu berkalung ukurannya 95 x $152 \mathrm{~mm}$. kelebihan media kartu tebak kata : 1. Mudah di bawa kemanapun 2. Mudah dan praktis dalam menggunakannya sehingga kapanpun anak didik bisa belajar menggunakan media ini dengan baik, 3.mudah diingat oleh siswa karena kartu di buat sangat menarik berisi huruf atau angka dan mudah merangsang otak lebih lama mengingat pesan pada kartu, 4.sangat menyenangkan di gunakan sebagai media pembelajaran dalam bentuk permainan (Indriana,2011:68-69).

Hal ini di perkuat dengan penelitian Menurut Nikmaul Fadilah (2015) yang mengatakan bahwa penelitiannya yang berjudul : Pengaruh Model Pembelajaran Make A Match Berbantuan Media Flashcard Terhadap Hasil Belajar Siswa Mata Pelajaran IPA Kelas V SDN Menganti 01 Jepara Tahun Pelajaran 2015/2016. Hasil analisis tes hasil belajar pada prestasi adalah 57,73, dan hasil belajar pada posttest adalah 85,45. Dari hasil tersebut, menunjukkan bahwa terdapat peningkatan hasil belajar dalam pembelajaran menggunakan model Make A Match berbantuan media Flashcard. Penelitian Sulistyaningsih 
(2014) menunjukkan bahwa penerapan model pembelajaran make a match berbantuan power point dilengkapi LKS dapat meningkatkan motivasi dan hasil belajar peserta didik. Sejalan dengan itu penelitian oleh Aisyah (2015) menunjukkan bahwa penerapan model pembelajaran kooperatif tipe Make A Match pada kompetensi dasar potongan bahan makanan dapat meningkatkan hasil belajar siswa.

Berdasarkan latar belakang masalah di atas, maka peneliti mengambil judul dalam penelitian ini yaitu : "Keefektifan model make a match berbantu media kartakalung terhadap hasil belajar matematika kelas V SDN Karangroto 04 Semarang".

\section{Metode}

Metode yang digunakan dalam penelitian ini adalah penelitian kuantitatif. Menurut Sugiyono (2015:11) mengemukakan bahwa metode kuantitatif dinamakan metode tradisional, karena metode ini sudah cukup lama digunakan sehingga sudah mentradisi sebagai metode untuk penelitian. Metode ini juga disebut metode konfirmatif, karena metode ini cocok digunakan untuk embuktian/konfirmasi. Metode ini disebut metode kuantitatif karena data penelitian berupa angka-angka dan analisis menggunkan statistik.

Teknik pengumpulan data merupakan wilayah langkah yang paling strategis dalam penelitian, karena tujuanya utama dari penelitian adalah mendapatkan data. Tanpa mengetahui teknik pengumpulan data, maka peneliti tidak akan mendapatkan data yang memenuhi standar data yang ditetapkan (Sugiyono, 2016:224). Untuk memenuhi data - data yang diperlukan dalam penelitian ini menggunkan beberapa metode antara lain :

1) Tes

Tes adalah sebuah instrumen pengumpulan data dalam penelitian untuk mengukur pengetahuan, pengalaman, dan ketrampilan responden (Jauhari,2010:156). Sedangkan menurut Arikunto (2010:193) tes adalah serentetan pertanyaan atau latihan atau alat lain yang digunakan untuk mengukur keterampilan, pengetahuan, intelegensi, kemampuan atau bakat yang dimiliki oleh individu atau kelompok. Metode tes digunakan peneliti untuk mendapatkan data nilai hasil belajar siswa setelah diberi perlakuan menggunakan model pembelajaran Make a Match. Dalam penelitian ini, tes yang diberikan dua kali yaitu sebelum kegiatan pembelajaran (pretest) dan sesudah kegiatan pembelajaran (posttest). Tes yang diberikan pada soal pretest dan posttest adalah soal yang sama yaitu berupa soal pilihan ganda.

2) Dokumentasi

Menurut Arikunto (2010: 274) metode dokumentasi yaitu mencari data mengenai hal-hal atau variable yang berupa catatan, transkip, buku, surat kabar, majalah, prasasti, notulen rapat, lengger, agenda, dan sebagainya. Dalam penelitian ini metode dokumentasi digunakan untuk mendapatkan datadata yang diperlukan dalam penelitian seperti daftar nama siswa, nilai kognitif siswa dari pretest dan posttestdan foto kegiatan pembelajaran di kelas V SD Negeri Karangroto 04 Semarang.

3) Wawancara

Wawancara yang digunakan dalam penelitian ini adalah wawancara tidak terstruktur. penelitian ini menyiapkan pokok-pokok wawancara berupa pertanyaan-pertanyaan yang akan ditanyakan kepada guru kelas bagaimana hasil belajar yang diperoleh siswa apakah sudah mencapai KKM 70.

\section{Hasil dan Pembahasan}

Penelitian ini dilaksanakan di SDN Karangroto 04 Semarang yang terdiri dari satu kelas dengan metode eksperimen sebagai metode penelitian yang digunakan untuk mencari pengaruh perlakuan tertentu. Dengan menggunakan rancangan penelitian pre-experimental dengan one group pretest posttest design yaitu dengan kegiatan pre-test di awal pembelajaran untuk mengetahui kemampuan awal siswa sebelum diberi perlakuan dan post-test pada akhir pembelajaran setelah siswa diberi perlakuan. Pada pembelajaran ini, siswa diberi perlakuan berupa model Make a match berbantu media Kartakalung. Populasi dalam penelitian ini adalah seluruh siswa kelas V dengan jumlah siswa 25. Penelitian dilaksanakan pada semester gasal tahun pelajaran 2018/2019.

Pada penelitian awal peneliti sudah melakukan uji instrumen untuk mendapatkan hasil validitas, reabilitas, daya pembeda, dan tingkat kesukaran soal, data diperoleh dari uji coba instrumen yang dilakukan di SDN Sendangmulyo 02 Semarang Tahun pelajaran 2018/2019 dengan soal sebanyak 50 soal. Soal yang akan digunakan sebagai instrumen dalam penelitian ini diujicobakan dahulu untuk mengetahui soal-soal yang termasuk kategori baik dan bisa digunakan sebagai instrumen penelitian. Setelah melakukan uji coba soal maka didapatkan hasil dari 50 soal terdapat 26 soal valid dan 24 soal tidak valid.

Soal yang valid digunakan sebagai instrumen penelitian atau soal yang diujikan kepada siswa ketika penelitian, setelah diperoleh hasil perhitungan data maka peneliti melakukan pemilahan soal pre- 
test dan post-test yang akan digunakan untuk penelitian di SDN Karangroto 04 Semarang tahun pelajaran 2018/2019.

Berdasarkan hasil pre-test dan post-test dapat diketahui bahwa terdapat nilai tertinggi, nilai terendah, dan nilai rata-rata hasil penelitian pre-test dan post-test. Deskripsi data pre-test dan posttest siswa dapat dilihat pada Tabel berikut :

Tabel 1. Deskripsi Nilai Rata-rata Pre-test dan Post-test

\begin{tabular}{llcc}
\hline No & Nilai & Nilai Terendah & Nilai Tertinggi \\
\hline 1 & Prestest & 40 & 90 \\
2 & Posttest & 70 & 95 \\
3 & Rata rata & 65 & 81 \\
4 & Presentase & $65 \%$ & $81 \%$ \\
\hline
\end{tabular}

Berdasarkan Tabel 1 diperoleh nilai pretest dan nilai postest yang menunjukan adanya perbedaan

signifikan. Hasil belajar pretest diperoleh rata - rata sebesar 65 dan nilai postest diperoleh rata rata sebesar 81 sehingga dapat disimpulkan bahwa perlakuan model pembelajaran make a match berbantu media kartakalung terdapat efektif terhadap hasil belajar. Temuan penelitian ini dikuatkan dengan hasil penelitian Dewi (2012) yang menemukan bahwa pembelajaran dengan melibatkan siswa dalam pemecahan masalah dapat mengontruksi pengetahuan siswaPerbedaan nilai hasil pretest dan postest dapat dilihat pada diagram sebagai berikut :

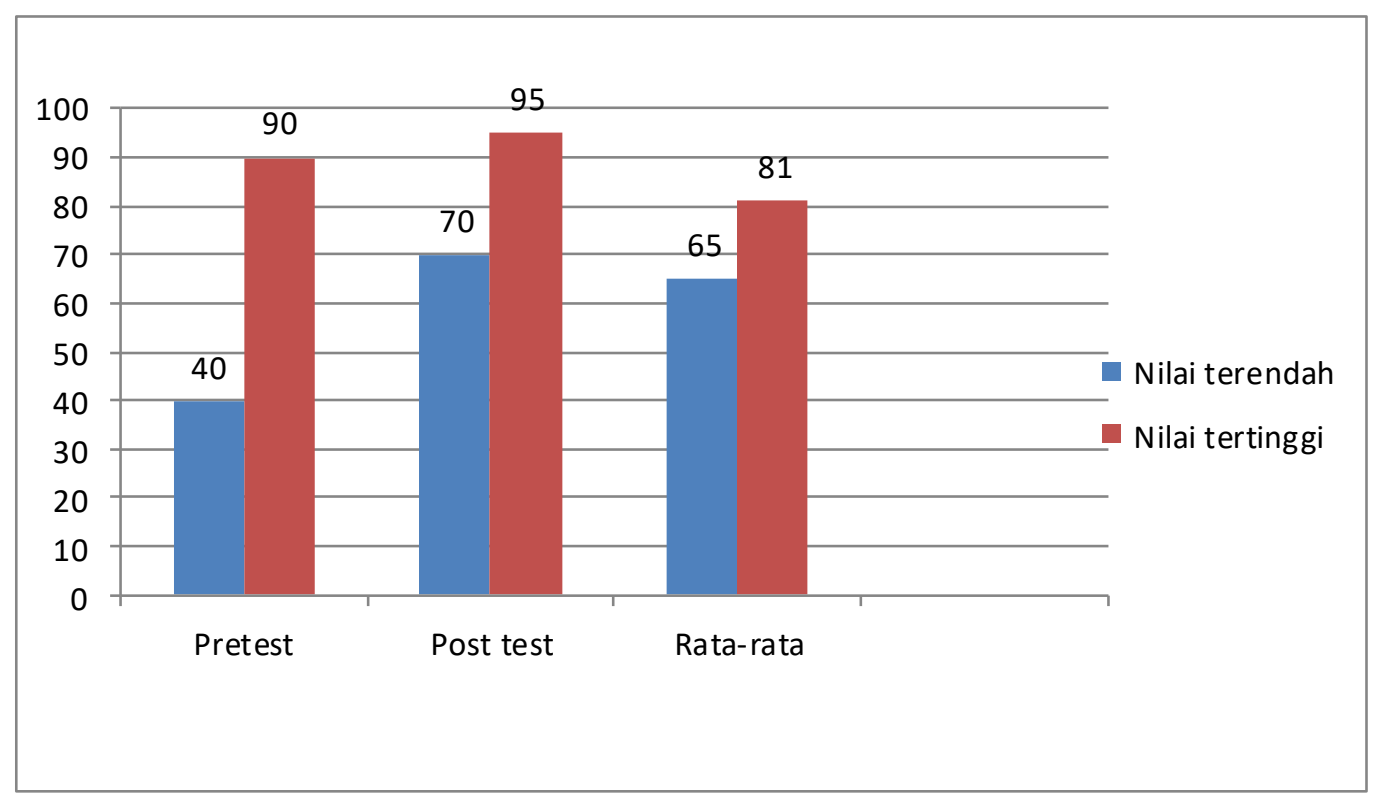

Grafik 1 Perbandingan Nilai Pre-test dan Post-test

\section{Uji Persyaratan Analisis Data}

\section{Analisis Data Awal (Uji Normalitas)}

Uji normalitas awal digunakan untuk mengetahui normal tidaknya data awal dari nilai pretest pada siswa kelas V SDN Karangroto 04 Semarang. Data berdistribusi normal apabila $\mathrm{L}_{0}<\mathrm{L}_{\text {tabel. }}$. Adapun hasil perhitungan normalitas dapat dilihat pada Tabel berikut ini:

Tabel 2. Daftar Uji Nurmalitas Nilai Pre-Test

\begin{tabular}{llll}
\hline Nilai & $\mathrm{L}_{0}$ & $\mathrm{~L}_{\text {tabel }}$ & Keterangan \\
\hline Pre-test & 0,146 & 0,173 & Berdistribusi Normal \\
\hline
\end{tabular}


Berdasarkan tabel 4.2 di atas diperoleh hasil perhitungan dari nilai $\mathrm{L}_{0}=0,183$ dengan $\mathrm{n}=25$ dan taraf signifikan $5 \%$ didapat $\mathrm{L}_{\text {tabel }}=0,173$ dengan diperoleh $\mathrm{L}_{\mathrm{o}}<\mathrm{L}_{\text {tabel }}$ atau $(0,146<0,206)$ dan $\mathrm{L}_{0}<\mathrm{L}_{\text {tabel }}$ atau $(0,146<0,173)$ maka $H_{a}$ diterima, sehingga sampel berasal dari populasi berdistribusi normal.

\section{Analisis Data Akhir (Uji Normalitas)}

Uji normalitas akhir digunakan untuk mengetahui normal tidaknya data akhir dari nilai posttest pada siswa kelas V SDN Karangroto 04 Semarang. Data berdistribusi normal apabila $\mathrm{L}_{0}<\mathrm{L}_{\text {tabel. }}$. Adapun hasil perhitungan normalitas dapat dilihat pada Tabel berikut ini:

Tabel 3. Daftar Uji Nurmalitas Nilai Post-Test

\begin{tabular}{llll}
\hline Nilai & $\mathrm{L}_{0}$ & Ltabel & Keterangan \\
\hline Post-test & 0,136 & 0,173 & Berdistribusi Normal \\
\hline
\end{tabular}

Berdasarkan tabel 4.3 di atas diperoleh hasil perhitungan dari nilai $\mathrm{L}_{0}=0,136$ dengan $\mathrm{n}=25$ dantaraf signifikan $5 \%$ didapat $\mathrm{L}_{\text {tabel }}=0,173$ dengan diperoleh $\mathrm{L}_{0}<\mathrm{L}_{\text {tabel }}$ atau $(0,136<0,173)$ dan $\mathrm{L}_{0}<\mathrm{L}_{\text {tabel }}$ atau $(0,136<0,173)$ maka $H_{a}$ diterima, sehingga sampel berasal dari populasi berdistribusi normal.

\section{Uji Hipotesis}

Analisis data akhir pada penelitian ini digunakan untuk menguji hipotesis yang diperoleh dari data perhitungan nilai pre-test dan post-test yang menunjukkan bahwa data berdistribusi normal. Kemudian data tersebut diuji efektif atau tidaknya model Make a Match berbantu media kartakalung untuk meningkatkan hasil belajar matematika siswa kelas V SDN Karangroto 04 Semarang menggunakan uji t-test.

1. Uji t-test

Uji hipotesis pada penelitian ini menggunakan uji-t dengan data nilai hasil belajar pretest dan posttest siswa kelas V di SDN Karangroto 04 Semarang.

Hipotesis statistik untuk keperluan t-test sebagai berikut:

$\mathrm{H}_{0}: \mu_{1}=\mu_{2}$ Tidak ada perbedaan signifikan antara pre-test post-test menggunakan Make a match berbantu media kartakalung terhadap hasil belajar matematika siswa kelas V SDN Karangroto 04 Semarang

$\mathrm{H}_{1}: \mu_{1} \neq \mu_{2}$ Ada perbedaan signifikan antara pre-test post-test menggunakan Model Make a match berbantu media kartakalung terhadap hasil belajar matematika siswa kelas VSDN Karangroto 04 Semarang

Data yang diperolah kemudian di olah menggunakan uji-t, pada hasil perhitungan sebelumnya menunjukkan hasil bahwa nilai pretest dan nilai posttest berdistribusi normal. Setelah dilakukan perhitungan, maka diperoleh hasil sebagai berikut:

Tabel 4. Hasi Perhitungan Uji-t Hasil Belajar Siswa

\begin{tabular}{llllllll}
\hline Subjek & Hasil Belajar & Rata-rata & N & Md & $\sum x^{2} d$ & $t_{\text {hitung }}$ & $t_{\text {tabel }}$ \\
\hline $\begin{array}{l}\text { Kelas V SDN } \\
\begin{array}{l}\text { Karangroto } \\
\text { 04 Semarang }\end{array}\end{array}$ & Pretest & 65 & 25 & 16,2 & & 5,665 & 2,060 \\
\hline
\end{tabular}

Berdasarkan analisis data hasil belajar tabel 4.4 nilai pretest dan posttest dengan uji-t diperoleh nilai rata-rata pretest 65 dan rata-rata nilai posttest 81,2. Diperoleh $t_{\text {hitung }}=5,665 \mathrm{db} N-1=25-1=24$ dengan taraf signifikan $5 \%$ sebesar 2,060 karena $t_{\text {hitung }}>t_{\text {tabel }}(5,665>2,060)$ maka hal ini menunjukan bahwa uji t hasil belajar signifikan. Hal ini menunjukan bahwa ada perbedaan hasil pre-test dan post-test menggunakan model pembelajaran Make a match berbantu media kartakalung terhadap hasil belajar matematika siswa kelas V SDN Karangroto 04 Semarang.

Ketuntasan Belajar

a. Ketuntasan Belajar Individu

Untuk mengetahui apakah nilai ketuntasan hasil belajar siswa dapat dicapai atau tidak setelah diterapkan pembelajaran menggunakan model Make a Match berbantu media kartakalung $\geq$ KKM 70 (KKM mata pelajaran matematika), maka digunakan rumus berikut: 


$$
\mathrm{KBI}=\frac{\text { skor yang diperoleh }}{\text { skor makismal }} \times 100
$$

Ketuntasan belajar siswa secara individual dinyatakan sudah tercapai apabila telah mendapatkan nilai sekurang-kurangnya 70.

Ketuntasan Belajar Klasikal

Ketuntasan belajar klasikal diharapkan dapat mencapai 70\%. Dalam menghitung ketuntasan hasil belajar menggunakan hasil pre-test dan post-test.

$$
\begin{aligned}
& \text { Pre-test }=\frac{14}{25} \times 100 \% \\
& =56 \%
\end{aligned}
$$

Hasil dari ketuntasan belajar klasikal pada pre-test terlihat jelas masih kurangnya nilai untuk mencapai nilai maksimum atau lebih dari $70 \%$ sehingga perlu mengatasinya dengan menerapkan model pembelajaran Make a match berbantu media kartakalung.

$$
\begin{aligned}
\text { Post-test } & =\frac{23}{25} \times 100 \% \\
& =92 \%
\end{aligned}
$$

Hasil dari ketuntasan belajar klasikal pada post-test dapat diketahui dengan pasti peningkatannya. Hal ini dikarenakan sudah diterapkan pembelajaran menggunakan model pembelajaran Make a match berbantu media kartakalung. Berdasarkan hasil diatas, dapat disimpulkan bahwa model pembelajaran Make a match berbantu media kartakalung dapat meningkatkan hasil belajar matematika siswa kelas $\mathrm{V}$ SDN Karangroto 04 Semarang. Penelitian ini sejalan dengan penelitian yang dilakukan oleh Nopiandari (2016) yang menunjukkan bahwa penerapan model make a match berbantuan media audio visual dapat meningkatkan hasil belajar IPA siswa kelas IV di SD Negeri 5 Banyuning. Penelitian Anggarawati (2014) menunjukkan bahwa model pembelajaran Make A Match berbantuan media kartu gambar berpengaruh terhadap hasil belajar IPS pada siswa kelas VI SD Negeri 26 Dangin Puri Tahun Pelajaran 2013/2014.

\section{Simpulan dan Saran}

Model Make a Match berbantu media Kartakalung efektif terhadap hasil belajar matematika siswa kelas V SDN Karangroto 04 Semarang. Kriteria kefektifan tersebut adalah: dari hasil uji t menunjukkan bahwa thitung >ttabel $(5,665>2,060)$ maka Ho ditolak sehingga dapat disimpulkan ada perbedaan signifikan antara pre-test dan post-test dengan menggunakan model make a match berbantu media kartakalung terhadap hasil belajar matematika siswa kelas V SDN Karangroto 04 Semarang. Hasil belajar siswa memenuhi ketuntasan secara klasikal yaitu melampaui 70\%, terdapat peningkatan hasil belajar siswa.

Berdasarkan hasil penelitian yang diperoleh, agar proses pembelajaran dapat memberikan hasil yang maksimal maka peneliti menyampaikan saran ntuk guru yaitu guru harus lebih kreatif dan variatif dalam memilih model dan media pembelajaran yang tepat dan disesuaikandengan materi yang akan di ajarkan agar hasil belajar siswa optimal. Pembelajaran dengan menggunakan model Make a Match berbantu media kartakalung dalam kegiatan belajar mengajar dapat membuat siswa tertarik dengan materi yang di sampaikan, siswa tidak merasa jenuh dan bosan. Pelaksanaan dalam pembelajaran ini lebih mengarah pada sistem belajar sambil bermain. Model pembelajaran Make a Match berbantu media kartakalung terbukti dapat meningkatkan hasil belajar siswa. Sedangkan bagi Pembaca dapat dijadikan salah satu referensi jika nantinya akan meneliti dengan model pembelajaran yang sama.

\section{Daftar Rujukan}

Aisyah, Nur Lindah, Luthfiyah Nurlaela. 2015. Penerapan Model Pembelajaran Kooperatif Tipe Make A Match Untuk Meningkatkan Hasil Belajar Siswa Kelas X Jasa Boga Pada Kompetensi Dasar Potongan Bahan Makanan Di Smk Negeri 1 Cerme, Gresik. e-journal Boga, Volume 4, No 1, Edisi Yudisium Periode Maret 2015, hal 143-152.

Anggarawati, I G. A. Ary, MG. Rini Kristiantari, I G. A. Agung Sri Asri. Pengaruh Make A Match Berbantuan Media Kartu Gambar Terhadap Hasil Belajar IPS SD. Jurnal Mimbar PGSD Universitas Pendidikan 
Ganesha Jurusan PGSD Vol: 2 No: 1

Arikunto,Suharsimi,2007, Dasar-dasar Evaluasi Pendidikan. Jakarta: PT.Bumi Aksara

Aqib, Zainal. 2013. Media Pembelajaran , Jakarta : Rajagrafindo persada.

Aunurrahman. 2009. Belajar dan Pembelajaran. Bandung: Alfabeta.

Chonstantika, Ade L., Haryono \& Sri Y. 2013. "Penerapan Pembelajaran Model Make A Match dan Diskusi Kelompok untuk Meningkatkan Motivasi Berprestasi, Rasa Ingin Tahu, dan Prestasi Belajar pada Materi Hidrokarbon Siswa Kelas X6 Di Sma Negeri 2 Boyolali Tahun Ajaran 2011/2012". Jurnal Pendidikan Kimia (JPK), Vol. 2, No. 3 (25-33)

Dimyati dan Mudjiono. (2009), Belajar dan Pembelajaran, Jakarta : PT. Rineka Cipta

Daryanto dan Rahardjo. 2012. Model Pembelajaran Inovatif, Yogyakarta:Penerbit Gava Media.

Dewi, N. R. V. 2012. Penerapan Model Pembelajaran Kooperatif Make A Match Berbantuan Media Kartu Bridge untuk Meningkatkan Hasil Belajar Matematika Siswa Kelas IV Semester I Tahun Pelajaran 2012/2013 Di SD Negeri Gulingan Kecamatan Mengwi. Skripsi. Tidak diterbitkan. Singaraja: Undiksha.

Djamarah dan Aswan. 2006. Strategi Belajar Mengajar, Jakarta: PTRineka Cipta.

Hamdani. 2011. Strategi Belajar Mengajar, Bandung: CV Pustaka Setia.

Huda,miftahul.2014.model-model Pengajaran dan Pembelajaran,Yogyakarta:Pustaka Pelajar.

Indriana,Dina,2011.Ragam Alat Bantu Media Pengajaran.Yogyakarta:diva Press.

Lie , A, (2008).Cooperative Learning di Ruang-ruang Kelas, Jakarta :PT.Gramedia.

Nopiandari, Ni Kadek, Ni Wayan Rati, Ni Wayan Arini. 2016. Penerapan Make A Match Berbantuan Media Audio Visual Untuk Meningkatkan Hasil Belajar IPA di SD. e-Journal PGSD Universitas Pendidikan Ganesha Jurusan PGSD Vol 4 No 1

Sipasulta, Ariel. 2014. Penerapan Model Pembelajaran Kooperatif Tipe Numbered head Together (NHT) pada Materi Pertolongan Pertama pada Kecelakaan (P3K) di Kelas X Jasa Boga 1 SMK Negeri 1 Buduran Sidoarjo. Skripsi tidak diterbitkan. Surabaya: PPs Universitas Negeri Surabaya.

Sirait, Makmur, Putri Adilah Noer. 2013. Pengaruh Model Pembelajaran Kooperatif Tipe Make A Match Terhadap Hasil Belajar Siswa. Jurnal INPAFI Volume 1, Nomor3

Slameto, (2013). Belajar dan Faktor-faktor yang mempengaruhinya,Jakarta:Rineka Cipta.

Soegeng, A Y .2013. Dasar-dasar Penelitian, Semarang Universitas PGRISemarang PRESS.

Soegeng A.Y. 2015. Dasar-Dasar Penelitian, Yogyakarta: MagnumPustaka Utama.

Sudjana. (2005). Metode Statistika. Bandung: Tarsito Bandung.

Sugiyono..(2010) Metode penelitian kuantitatif kualitatif \&RND.Bandung:Alfabeta.

(2012) Memahami Penelitian Kualitatif.Bandung : ALFABETA

.... (2013).Memahami Penelitian Pendidikan (Pendekatan Kuantitatif, Kualitatif, dan RND). Bandung: Alfabeta.

Sugiyono. 2015. Metode Penelitian Pendidikan, Bandung: Alfabeta. 
Sulistyaningsih, Febriyani, Sri Mulyani, dan Suryadi Budi Utomo. 2014. Penerapan Model Pembelajaran Make A Match Berbantuan Power Point Dilengkapi Lks Untuk Meningkatkan Motivasi Dan Hasil Belajar Pada Pokok Bahasan Isomer Dan Reaksi Senyawa Hidrokarbon Kelas X Sma Batik 1 Surakarta Tahun Pelajaran 2012/2013. JPK, Jurnal Pendidikan Kimia Vol. 3 No. 2 Tahun 2014 Hal. 82-87

Sundayana, Rostina. 2015. Media dan Alat Peraga Dalam Pembelajaran

Matematika, Bandung: Alfabeta.

Susanto, Ahmad. 2013. Teori belajar \& Pembelajaran di Sekolah dasar.Jakarta: Prenadamedia Group.

Suprijono, A . (2012). Kooperative Learning :Teori \& Aplikasi Paikem,Yogyakarta: Pustaka Pelajar.

Wiguna, I Kd. Adi, Md Sumantri, Gd Raga. 2014. Pengaruh Model Pembelajaran Cooperative Tipe Make A Match Terhadap Hasil Belajar Matematika Siswa Kelas Iv Di Gugus III Kecamatan Rendang. Jurnal Mimbar PGSD Universitas Pendidikan Ganesha Jurusan PGSD Vol. 2 No. 1

Wijaya, dkk 2014. Pengaruh pembelajaran kooperatif tipe make a match terhadap hasil belajar matematika siswa kelas IV di gugus III Kecamatan Rendang. Jurnal. Semarang: Universitas Negeri Semarang. 